\title{
PENYELESAIAN WANPRESTASI PERJANJIAN SEWA MENYEWA MOBIL (STUDI KASUS PT. BALI RADIANCE)
}

\author{
Kadek Januarsa Adi Sudharma(1), \\ januarsa.adi@undiknas.ac.id(1); \\ Fakultas Hukum dan IImu Sosial Undiknas Denpasar
}

\begin{abstract}
PT. Bali Radiance is one of the biggest car lease firm in Badung Regency. PT. Bali Radiance has at least 107 vehicles which are ready to be leased. The leasing begins with making a car lease agreement. In the agreement of car lease, breach of contract is still frequent. Based on the data of breach of contract which had happened in PT. Bali Radiance from year 2015 to 2017, in 2015104 breach of contract's cases were found, in 2016130 cases were found and in 2017100 cases were found. These findings require some settlement that are balanced and fair, so the rights and obligations of the tenants and PT. Bali Radiance are well-accommodated in accordance with the car lease agreement. Based on the result of research about car lease agreement, breach of contract is frequent both intentional and unintentional. Where in the breach of contract can be settled by litigation path or non litigation path. Breach of contract that had happened in PT. Bali Radiance frequently done by the tenants such as late return of the car and disfiguration of the car. That breach of contract can be settled by non litigation path in example mediation or negotiation. As for other kind of breach of contract which is classified as serious in example the car is mortgaged by the tenant, can be settled by litigation path or bring it to court.

Keywords: Lease Agreement, Breach of Contract, Dispute Settlemen
\end{abstract}

\section{ABSTRAK}

PT. Bali Radiance adalah salah satu perusahaan penyewaan mobil terbesar di Kabupaten Badung. PT. Bali Radiance memiliki setidaknya 107 kendaraan yang siap disewakan. Leasing dimulai dengan membuat perjanjian sewa mobil. Dalam perjanjian sewa mobil, pelanggaran kontrak masih sering terjadi. Berdasarkan data pelanggaran kontrak yang pernah terjadi di PT. Bali Radiance dari tahun 2015 hingga 2017, pada tahun 2015104 pelanggaran kasus kontrak ditemukan, pada tahun 2016130 kasus ditemukan dan pada tahun 2017100 kasus ditemukan. Temuan ini membutuhkan beberapa penyelesaian yang seimbang dan adil, sehingga hak dan kewajiban para penyewa dan PT. Bali Radiance terakomodasi dengan baik sesuai dengan perjanjian sewa mobil. Berdasarkan hasil penelitian tentang perjanjian sewa mobil, pelanggaran kontrak sering dilakukan secara sengaja dan tidak disengaja. Dimana dalam pelanggaran kontrak dapat diselesaikan dengan jalur litigasi atau jalur non litigasi. Pelanggaran kontrak yang pernah terjadi di PT. Bali Radiance sering dilakukan oleh para penyewa seperti keterlambatan kembalinya mobil dan disfigurasi mobil. Pelanggaran kontrak dapat diselesaikan dengan jalur non litigasi dalam mediasi atau negosiasi contoh. Adapun bentuk lain dari pelanggaran kontrak yang tergolong serius misalnya mobil digadaikan oleh penyewa, dapat diselesaikan dengan jalan litigasi atau membawanya ke pengadilan

Kata Kunci: Perjanjian Sewa, Pelanggaran Kontrak, Penyelesaian Sengketa 


\section{PENDAHULUAN}

Dewasa ini, sarana transportasi sangat diperlukan untuk menunjang aktivitas masyarakat, yaitu untuk mempermudah usaha atau aktivitas lainnya. Tidak sedikit masyarakat yang lebih memilih jasa penyewaan transportasi terutama mobil untuk mempercepat sistem kerja.

Provinsi Bali merupakan salah satu tujuan wisata. Dinas Pariwisata Provinsi Bali mencatat di tahun 2016 wisatawan lokal yang berkunjung ke Bali sebanyak 8.643.680 wisatawan dan wisatawan mancanegara sebanyak 4.927.937 wisatawan. ${ }^{1}$ Wisatawan yang berkunjung ke Bali pasti membutuhkan sarana transportasi untuk mempermudah perjalanan wisata wisatawan tersebut. Di Bali, khususnya Kabupaten Badung sangat mudah menemukan tempat penyewaan mobil, salah satunya adalah PT. Bali Radiance, yang beralamat di Jalan Raya Basangkasa No. 1009 Kuta Utara. PT. Bali Radiance merupakan badan usaha hukum yang bergerak dibidang penyediaan jasa transportasi roda empat (mobil) dengan Surat Izin Usaha Nomor : 112/IUA/BR/2002.

PT. Bali Radiance memiliki setidaknya 107 armada yang siap untuk disewakan. Terhitung dari tahun 2015 sampai bulan Agustus tahun 2017, jumlah penyewa yang menggunakan jasa PT. Bali Radiance sebanyak 5.830 penyewa. ${ }^{2}$ Untuk menyewa mobil di PT. Bali Radiance, pihak penyewa harus menyetujui perjanjian yang telah dibuat oleh pihak PT. Bali Radiance, dimana perjanjian tersebut mengatur ketentuan seperti, jangka waktu penyewaan, syarat-syarat sebagai penyewa, hak dan kewajiban sebagai penyewa.

Pada sebuah perjanjian pasti kedua belah pihak menginginkan tercapainya prestasi, tetapi tidak jarang terjadi wanprestasi. Prestasi berasal dari bahasa Belanda "prestatie" yang berarti ketepatan janji untuk memenuhi isi perjanjian, sedangkan wanprestasi atau ingkar janji berarti prestasi yang buruk. Wanprestasi terjadi apabila dalam suatu perjanjian salah satu pihak tidak melakukan kewajibannya. ${ }^{3}$

\footnotetext{
${ }^{1}$ http://www.disparda.baliprov.go.id/id/Statistik3 diakses tanggal 30 Agustus 2017

2 Hasil wawancara dengan Ibu Ni Ketut Candrawati, S.S., selaku Staff Oprational PT. Bali Radiance, tanggal 27 Agustus 2018.

${ }^{3}$ Sudarsono, 2007, Kamus Hukum, PT. Rineka Cipta, Jakarta, h. 371.
} 
Menurut penjelasan Ibu Ni Ketut Candrawati, S.S., selaku Staff Operational PT. Bali Radiance, Pada PT.Bali Radiance, wanprestasi dapat terjadi apabila dalam perjanjian terjadi :

1. Tidak memberitahukan 2 (dua) jam sebelum masa sewa berakhir terkait dengan konfirmasi pengembalian mobil atau perpanjangan masa sewa mobil.

2. Pengembalian mobil tidak dilakukan tepat waktu.

3. Lalai dalam menjaga mobil pada saat masa penyewaan sehingga terjadi kerusakan pada mobil, baik kerusakan ringan maupun kerusakan berat.

4. Melakukan sesuatu yang dilarang dalam perjanjian, menggadaikan mobil dan menjadikan mobil yang disewa sebagai jaminan tertentu.

Berdasarkan data wanprestasi yang pernah terjadi di PT. Bali Radiance dari tahun 2015 sampai tahun 2017, yaitu pada tahun 2015 telah tejadi 104 kasus wanprestasi, tahun 2016 sebanyak 130 kasus wanprestasi dan tahun 2017 (terhitung sampai dengan bulan Agustus 2017) sebanyak 100 kasus wanprestasi.

Hal ini tentu saja memerlukan penyelesaian wanprestasi yang berimbang dan adil, agar hak dan kewajiban antara penyewa dan PT.Bali Radiance tetap terakomodasi dengan baik sesuai dengan perjanjian sewa menyewa yang telah disepakati.

\section{PEMBAHASAN}

\section{Ketentuan dan Syarat Perjanjian Sewa Menyewa Mobil Pada PT. Bali Radiance}

Penyewaan mobil di Bali merupakan alternatif bagi masyarakat yang memerlukan mobil untuk menunjang aktivitasnya. Usaha dibidang jasa sewa menyewa mobil sudah sangat pesat pertumbuhannya terutama di Kabupaten Badung. Salah satu usaha jasa sewa menyewa mobil di Kabupaten Badung adalah PT. Bali Radiance. Untuk dapat menyewa mobil di PT. Bali Radiance, pihak yang akan menyewa harus memenuhi syarat dan ketentuan pada perjanjian sewa menyewa mobil yang sudah dibuat dan ditetapkan oleh pihak PT. Bali Radiance selaku pihak yang menyewakan. 
Pada umumnya bentuk perjanjian sewa menyewa ada dua macam yaitu perjanjian sewa menyewa dalam bentuk lisan dan perjanjian sewa menyewa dalam bentuk tertulis. Perjanjian sewa menyewa mobil pada PT. Bali Radiance merupakan perjanjian sewa menyewa dalam bentuk tertulis, yang pada perjanjian sewa menyewa tersebut memuat syarat dan ketentuan bagi pihak penyewa. Adapun syarat-syarat tersebut adalah

1) Pengemudi harus memiliki SIM A/SIM Internasional yang masih berlaku

2) Memiliki KTP yang masih berlaku

3) Memiliki Visa/Paspor

4) Meninggalkan sepeda motor dan STNK penyewa

5) Membayar sejumlah uang sebagai biaya sewa

6) Menandatangani surat perjanjian sewa menyewa mobil

Pasal $1320 \mathrm{KUH}$ Perdata mengatur syarat sahnya perjanjian sewa menyewa, yaitu ${ }^{4}$ :

1) Syarat Subjektif (kecakapan untuk membuat perjanjian dan kesepakatan mereka yang membuat perjanjian).

2) Syarat Objektif (suatu hal atau objek tertentu dan suatu sebab yang halal).

Berdasarkan syarat sahnya perjanjian di atas dan dihubungkan dengan syarat yang ada pada PT. Bali Radiance, maka yang termasuk syarat subjektif yang pertama yaitu kecakapan untuk membuat perjanjian adalah memiliki SIM A/SIM Internasional, memiliki KTP yang masih berlaku dan memiliki Visa/Paspor. Syarat subjektif kedua yaitu kesepakatan mereka yang membuat perjanjian adalah meninggalkan sepeda motor/STNK, membayar biaya sewa dan menandatangani surat perjanjian sewa menyewa mobil. Dengan adanya kesepakatan tersebut, maka perjanjian ini sudah berjalan dan mengikat kedua belah pihak, hal ini juga sesuai dengan asas konsesualisme yang menyatakan bahwa salah satu syarat sahnya perjanjian adalah adanya kata sepakat antara kedua belah pihak. Apabila syarat subjektif ini tidak terpenuhi, maka perjanjian sewa menyewa ini dapat dibatalkan (avoid of law/vernietigbaar).

Selanjutnya berdasarkan syarat objektif yang pertama yaitu suatu

${ }^{4}$ Abdul R. Saliman, 2015, Hukum Bisnis untuk Perusahaan, Prenamedia Group, Jakarta, h. 39 
hal atau objek tertentu yang sudah secara jelas termuat bahwa objek yang disewa merupakan sebuah kendaraan (mobil). Dan syarat objektif kedua yaitu suatu sebab yang halal, ini berarti bahwa isi dari perjanjian sewa menyewa mobil pada PT. Bali Radiance memiliki sebab yang tidak bertentangan dengan Undang-Undang yang berlaku, dimana pihak penyewa menginginkan kenikmatan dalam penyewaan mobil selama masa sewa dan pihak PT. Bali Radiance selaku pihak yang menyewakan menghendaki biaya sewa dari penyewaan tersebut. Apabila syarat objektif ini tidak terpenuhi, maka perjanjian sewa menyewa ini akan batal demi hukum (null and void of law/nietiganrechtswege).

Harga sewa mobil pada PT. Bali Radiance berbeda-beda berdasarkan jenis mobilnya. Harga sewa mobil berkisar dari Rp 100.000/hari sampai dengan Rp. 2.000.000/hari. Selanjutnya adalah ketentuan-ketentuan yang telah ditetapkan oleh PT. Bali Radiance, yaitu sebagai berikut :

1) Biaya untuk penggunaan sopir adalah $\mathrm{Rp} 100.000 / 8$ jam dan jika melebihi waktu tersebut, dikenakan biaya tambahan sebesar $\mathrm{Rp}$ 20.000/jam.

2) Asuransi terhadap kendaraan adalah berdasarkan permintaan penyewa dan biayanya adalah Rp 50.000/hari. Asuransi dapat digunakan terhadap kerusakan pada mobil tetapi tidak dapat digunakan apabila terjadi kehilangan atau terhadap orang ketiga.

3) Bila sewa kendaraan dengan asuransi, maka jika terjadi kecelakaan atau kerusakan, penyewa hanya dikenakan biaya klaim asuransi sebesar US \$ 100 diluar biaya sewa.

4) Bila sewa tanpa asuransi, maka kecelakaan, kerusakan, kehilangan kendaraan atau bagian-bagiannya akan sepenuhnya menjadi tanggung jawab penyewa.

5) Harga sewa adalah untuk pemakaian kendaraan selama minimal 8 jam dan maksimal 24 jam sehari. Jika melebihi waktu tersebut, maka penyewa akan dikenakan biaya tambahan sebesar Rp 20.000/jam.

6) Penyewa akan sepenuhnya bertanggung jawabatas kerusakan pada kendaraan atau kehilangan bagian-bagiannya jika kendaraan dikendarai diluar jalur jalan raya, seperti pantai, sawah, dll. 
7) Penyewa akan bertanggung jawab sepenuhnya sebagai akibat yang terjadi apabila kendaraan diberikan kepada orang lain/dikendarai oleh orang lain selain penyewa.

8) Tidak diijinkan membawa/mengendarai kendaraan keluar Pulau Bali.

9) Pembatalan atas pemesanan sewa kendaraan akan dikenakan biaya sebesar $50 \%$ dari harga sewa sehari.

Berdasarkan unsur-unsur perjanjian sewa menyewa yang ada apabila dikaitkan dengan pembahasan diatas, yaitu :

1) Unsur Essensialia merupakan unsur mutlak yang ada dalam perjanjian, yaitu jenis mobil yang disewa, harga sewanya dan juga jangka waktu penyewaan yang ada di dalam perjanjian sewa menyewa mobil pada PT. Bali Radiance.

2) Unsur Naturalia merupakan unsur yang tidak diperjanjikan secara khusus, tetapi telah melekat dalam perjanjian tersebut. Hal ini berarti ketentuan tersebut tidak tercantum dalam perjanjian sewa menyewa mobil ini, tetapi secara langsung harus dilaksanakan karena sudah diatur dalam Undang-Undang. Contohnya Pasal 1575 yang menyatakan : "perjanjian sewa tidak sekali-kali hapus dengan meninggalnya pihak yang menyewakan maupun dengan meninggalnya pihak yang menyewa." Ini berarti apabila salah satu pihak meninggal dunia maka perjanjian tetap berjalan sampai perjanjian tersebut berakhir dengan mengalihkan hak dan kewajiban tersebut kepada ahli waris walaupun ketentuan ini tidak tercantum dalam perjanjian sewa menyewa mobil pada PT. Bali Radiance. Contoh lainnya yaitu mengenai force majeure, yang diatur dalam Pasal $1244 \mathrm{KUH}$ Perdata yang menyatakan :

Debitur harus dihukum untuk mengganti biaya, kerugian dan bunga bila ia tak dapat membuktikan bahwa tidak dilaksanakannya perikatan itu atau tidak tepatnya waktu dalam melaksanakan perikatan itu disebabkan oleh sesuatu hal yang tak terduga, yang tak dapat dipertanggungkan kepadanya walaupun tidak ada itikad buruk kepadanya.

Dan Pasal 1245 KUH Perdata menyatakan :

Tidak ada penggantian biaya, kerugian dan bunga bila karena keadaan memaksa atau karena hal yang terjadi secara kebetulan, debitur terhalang untuk memberikan atau berbuat sesuatu yang diwajibkan atau melakukan suatu perbuatan yang terlarang baginya. 
Jadi, apabila dalam perjanjian sewa menyewa terjadi wanprestasi yang disebabkan karena force majeure atau kejadian yang tidak terduga, dan dalam perjanjian sewa menyewa tersebut tidak mengatur mengenai force majeure, maka penyelesaian wanprestasi tersebut akan dilakukan berdasarkan Pasal 1244 dan 1245 KUH Perdata.

3) Unsur Accidentalia merupakan unsur yang ditambahkan oleh para pihak karena tidak diatur dalam Undang-Undang, yaitu seluruh ketentuan yang ditetapkan oleh PT. Bali Randiance seperti pengaturan biaya tambahan, biaya asuransi dan juga cara penyelesaian yang dapat dilakukan pihak penyewa.

Perjanjian sewa menyewa mobil pada PT. Bali Radiance dibuat dengan berlandaskan asas kebebasan berkontrak, dimana UndangUndang memberikan kebebasan kepada siapapun yang akan membuat perjanjian, asal tidak bertentangan dengan Undang-Undang, kesusilaan dan ketertiban umum. Adapun kebebasan yang dimaksud, yaitu ${ }^{5}$ :

1) Bebas membuat atau tidak membuat perjanjian.

2) Bebas mengadakan perjanjian dengan siapapun.

3) Bebas menentukan isi perjanjian dan syarat-syaratnya.

4) Bebas menentukan bentuk perjanjiannya.

Kebebasan tersebut secara jelas diberikan kepada siapapun yang akan membuat perjanjian, dimana PT. Bali Radiance membuat perjanjian sewa menyewa mobil, dan perjanjian tersebut diadakan dengan siapa saja yang ingin menyewa mobil pada PT. Bali Radiance, dengan memenuhi segala syarat dan ketentuan yang telah ditentukan oleh PT. Bali Radiance dan tercantum dalam perjanjian sewa menyewa mobil. Dimana perjanjian tersebut dibuat dalam bentuk tertulis sehingga disebut surat perjanjian sewa menyewa mobil.

Apabila segala syarat dan ketentuan telah disepakati oleh pihak penyewa, maka perjanjian sewa menyewa mobil pada PT. Bali Radiance tersebut menjadi sah dan berlaku serta mengikat kedua belah pihak layaknya Undang-Undang, yang harus dilaksanakan sesuai dengan isi dari perjanjian sewa menyewa mobil tersebut, sebagaimana dengan asas pacta sunt servanda yang menyatakan bahwa perjanjian yang dibuat secara sah

5 Much. Nurachmad, 2010, Buku Memahami dan Membuat Surat Perjanjian, Visimedia, Jakarta, h. 14 
akan mengikat sebagai Undang-Undang bagi para pihak yang membuatnya. ${ }^{6}$

Setelah syarat dan ketentuan telah disepakati oleh kedua belah pihak, maka kedua belah pihak harus mengerti dan memahami hak dan kewajiban yang timbul dari perjanjian sewa menyewa mobil tersebut. Berikut adalah hubungan hukum para pihak dalam perjanjian sewa menyewa yang merupakan hak dan kewajiban dari para pihak, yaitu:

1) Kewajiban pihak yang menyewakan

Pasal $1550 \mathrm{KUH}$ Perdata menyatakan tiga macam kewajiban pokok dari pihak yang menyewakan yaitu :

(a) Wajib untuk menyerahkan (leveran) barang yang disewakan kepada pihak penyewa.

(b) Wajib untuk memelihara barangnya sedemikian rupa, sehingga barangnya dapat dipakai untuk keperluan yang dimaksud.

(c) Wajib untuk memberikan hak kepada penyewa untuk menikmati barang yang disewakan itu dengan tentram (rusting genot) selama berlangsungnya sewa.

2) Hak dari pihak yang menyewakan, yaitu :

(a) Berhak mendapatkan biaya sewa yang harus dibayar oleh pihak penyewa tepat waktunya sesuai dengan perjanjian.

(b) Pihak yang menyewakan berhak untuk menuntut ganti rugi kepada pihak penyewa apabila barang yang disewakan rusak.

3) Kewajiban pihak penyewa

Pasal 1560 KUH Perdata menyatakan kewajiban pokok dari pihak penyewa, yaitu :

(a) Wajib untuk memakai barang sewaan secara berhati-hati sesuai dengan tujuan barang itu menurut perjanjian sewa menyewa atau jika tidak ada persetujuan mengenai hal itu, sesuai dengan tujuan barang itu menurut persangkaan menyangkut keadaan.

(b) Wajib untuk membayar biaya sewa tepat pada waktu yang telah ditentukan.

(c) Wajib untuk bertanggung jawab atas segala kerusakan yang ditimbulkan pada barang yang disewa selama waktu sewa, kecuali jika ia membuktikan bahwa kerusakan itu terjadi diluar kesalahannya.

4) Hak dari pihak penyewa, yaitu :

(a) Berhak ketika penyerahan barang yang disewa harus dalam keadaan terpelihara sehingga dapat dipergunakan untuk keperluan yang dimaksud.

${ }^{6}$ Ibid, h. 15 
(b) Berhak atas jaminan dari pihak yang menyewakan akan tidak adanya cacat dari barang yang disewa.

(c) Berhak untuk mendapatkan perlindungan hukum dari pihak yang menyewakan, agar pihak penyewa dalam mempergunakan dan menikmati barang yang disewakannya dapat dengan tentram dan damai serta tidak adanya akibat yang merintangi pemakaian barang yang disewanya.

Hak dan kewajiban para pihak harus dimengerti dan dipahami sebagaimana yang telah menjadi kesepakatan kedua belah pihak, para pihak juga harus melaksanakan segala kewajibannya sebagai bentuk hubungan hukum atas perjanjian yang disepakati sehingga para pihak dapat menerima haknya. Apabila salah satu pihak tidak melaksanakan kewajibannya, maka dapat mengakibatkan pihak lain tidak mendapatkan haknya atau mengalami kerugian.

\section{Penyelesaian Wanprestasi Pihak Penyewa dalam Perjanjian Sewa Menyewa Mobil Pada PT. Bali Radiance}

Wanprestasi atau ingkar janji adalah tidak terpenuhinya kewajiban (prestasi) sebagaimana yang ditentukan dalam perjanjian yang dibuat antara kreditur dengan debitur. ${ }^{7}$ Akibat yang timbul oleh debitur (pihak penyewa) yang melakukan wanprestasi dalam suatu perjanjian sewa menyewa menyebabkan seorang kreditur (pihak yang menyewakan yaitu PT. Bali Radiance) tidak mendapatkan pemenuhan hak-haknya.

Kreditur yang tidak mendapatkan pemenuhan atas hak-haknya, mengakibatkan kreditur mengalami kerugian. Oleh karena itu debitur yang tidak melaksanakan kewajibannya harus bertanggung jawab atas kerugian tersebut. Dikenakannya sanksi hukum terhadap suatu keadaan terjadinya wanprestasi pada suatu perjanjian yang merupakan suatu hubungan hukum adalah karena dalam suatu perjanjian mengandung teori tanggung jawab hukum, yaitu pihak debitur harus bertanggung jawab atas segala kerugian yang ditimbulkan sebagai bentuk pertanggung jawabannya karena tidak melaksanakan kewajiban sebagaimana mestinya dalam perjanjian sewa menyewa.

\footnotetext{
${ }^{7}$ Rocky Marbun, 2011, Kasus Hukum, Visimedia, Jakarta, h. 201.
} 
Teori tanggung jawab dalam perbuatan melanggar hukum (tort liability) menurut Abdulkadir Muhammad, yaitu ${ }^{8}$ :

1) Tanggung jawab akibat perbuatan melanggar hukum yang dilakukan dengan sengaja (intentional tort liability).

2) Tanggung jawab akibat perbuatan melanggar hukum yang dilakukan karena kelalaian (negligence tort liability).

3) Tanggung jawab mutlak akibat perbuatan melanggar hukum tanpa mempersoalkan kesalahan (strict liability).

Teori tanggung jawab hukum ini juga berkaitan dengan sebab terjadinya wanprestasi, yaitu ${ }^{9}$ :

1) Kesalahan debitur karena kesengajaan.

2) Kesalahan debitur karena kelalaian.

3) Kesalahan debitur karena keadaan memaksa (force majeure).

Berdasarkan sebab terjadinya wanprestasi di atas, maka ada 4 macam bentuk wanprestasi, yaitu ${ }^{10}$ :

a) Tidak melakukan apa yang disanggupi akan dilakukannya.

b) Melaksanakan apa yang yang diperjanjikan, tetapi tidak sebagaimana diperjanjikan.

c) Melakukan apa yang diperjanjikan tetapi terlambat.

d) Melakukan sesuatu yang menurut perjanjian tidak boleh dilakukannya.

Pada PT. Bali Radiance, pihak penyewa sering melakukan wanprestasi. Berdasarkan data wanprestasi dari tahun 2015 sampai tahun 2017, telah terjadi 288 kasus keterlambatan pengembalian mobil dan 46 kasus kerusakan mobil yang disewa akibat kelalaian pihak penyewa.

Berdasarkan pemaparan diatas berarti apapun sebab atau alasan terjadinya wanprestasi yang terjadi, debitur tetap harus bertanggung jawab. Adapun akibat hukum yang termuat dalam Pasal 1243 KUH Perdata, yang menyatakan bahwa ${ }^{11}$ :

8 Abdulkadir Muhammad, 2010, Hukum Perusahaan Indonesia, Citra Aditya Bakti, Bandung, h. 535

9 Dr. Ronald Saija, \& Roger F.X.V Letsoin, 2016, Buku Ajar Hukum Perdata, Deepublish, Yogyakarta, h. 145

10 R. Subekti, 2010, Hukum Perjanjian, cet. 23, (selanjutnya disebut R. Subekti II), PT. Intermasa, Jakarta, h. 45

${ }^{11}$ Agus Yudha Hernoko, 2014, Hukum Perjanjian, cet. Ke-4, Prenamedia Group, Jakarta, h. 261 
Penggantian biaya, rugi dan bunga karena tidak dipenuhinya suatu perikatan, barulah mulai diwajibkan apabila si berhutang telah dinyatakan lalai memenuhi perikatannya, tetap lalai untuk memenuhi perikatan itu atau jika sesuatu yang harus diberikan atau dilakukannya hanya dapat diberikan dalam waktu yang melampaui waktu yang telah ditentukan.

Pengenaan penggantian biaya, rugi dan bunga dalam upaya menyelesaikan sengketa wanprestasi merupakan salah satu akibat hukum yang ditimbulkan oleh wanprestasi itu sendiri. Menurut R. Subekti tentang akibat hukum sebagai tanggung jawab debitur atas keadaan wanprestasi tersebut adalah ${ }^{12}$ :

1) Membayar kerugian yang diderita oleh kreditur atau dengan singkat dinamakan ganti rugi.

2) Pembatalan perjanjian atau juga dinamakan pemecahan perjanjian.

3) Peralihan resiko.

4) Membayar biaya perkara, jika sampai dipekarakan di depan hakim.

Berdasarkan hasil wawancara dengan Ibu Ni Ketut Candrawati, S.S, selaku staff operational PT. Bali Radiance, memberikan akibat hukum bagi debitur (pihak penyewa) yang wanprestasinya, yaitu :

1) Pihak penyewa diwajibkan untuk membayar ganti rugi atas segala hal yang ia perbuat diluar hak-hak yang dimiliki dan atas segala hal yang dilakukan diluar perjanjian yang telah disepakati.

2) Resiko terhadap mobil beralih kepada pihak penyewa sejak terjadinya wanprestasi.

3) Pihak penyewa wajib membayar biaya perkara apabila hal ini diperkarakan dimuka pengadilan.

4) Memenuhi perjanjian yang dibuat setelah terjadi dan terbukti melakukan wanprestasi.

Pada umumnya, penyelesaian sengketa dapat diselesaikan melalui 2 jalur penyelesaian sengketa yaitu penyelesaian sengketa secara litigasi (suatu penyelesaian sengketa yang dilakukan dengan melalui pengadilan) dan penyelesaian sengketa melalui non litigasi (penyelesaian sengketa yang dilakukan di luar pengadilan). ${ }^{13}$ Penyelesaian sengketa yang biasa digunakan oleh pelaku usaha bisnis adalah penyelesaian melalui jalur non litigasi (di luar pengadilan).

\footnotetext{
12 R. Subekti II, loc cit.

13 Jimmy Joses Sembiring, 2011, Cara Menyelesaikan Sengketa di Luar Pengadilan, Visimedia, Jakarta, h. 9.
} 
Berdasarkan jenis dan data wanprestasi yang telah tercantum dalam latar belakang, jelas bahwa wanprestasi tersebut berbeda-beda. Maka dari itu, untuk mengetahui bagaimana cara penyelesaian wanprestasi tersebut berdasarkan jenis wanprestasi yang dilakukan maka harus dihubungkan dengan teori tanggung jawab hukum menurut Abdulkadir Muhammad tersebut, yaitu :

1) Intentional tort liability, merupakan tanggung jawab akibat perbuatan melanggar hukum yang dilakukan dengan sengaja. Bentuk wanprestasi karena kesengajaan ini adalah dimana debitur melakukan sesuatu yang menurut perjanjian tidak boleh dilakukan. Wanprestasi yang tergolong karena kesengajaan, misalnya digadaikannya mobil sewaan oleh pihak penyewa kepada orang ketiga. Digadaikannya mobil sudah termasuk tindak pidana penggelapan, karena telah memenuhi unsur-unsur penggelapan sesuai dengan Pasal 372 Kitab Undang-Undang Hukum Pidana (KUHP), yaitu ${ }^{14}$ :

(1) Unsur Objektif, yaitu memiliki barang yang seluruhnya atau sebagian milik orang lain; barang itu ada padanya atau dikuasainya bukan karena kejahatan.

(2) Unsur Subjektif, yaitu dengan sengaja; dengan melawan hukum.

Kedua unsur ini telah terpenuhi, yaitu dimana pihak penyewa dengan sengaja mengaku sebagai pemiliki mobil yang disewanya dan melakukan hal yang tidak menjadi haknya sebagai penyewa mobil yaitu menggadaikan mobil tersebut kepada pihak ketiga tanpa persetujuan pihak yang menyewakan selaku pemilik mobil (PT. Bali Radiance) dan mengambil keuntungan dari hal yang dilarang tersebut.

Pada PT. Bali Radiance, belum pernah terjadi kasus digadaikannya mobil yang dilakukan oleh pihak penyewa. Apabila kasus ini terjadi pada PT.Bali Radiance, maka kasus ini tidak lagi diselesaikan melalui jalur non litigasi, akan tetapi PT. Bali Radiance akan langsung melaporkan hal tersebut kepada pihak yang berwajib dan membawa sengketa wanprestasi ini ke ranah pengadilan.

Wanprestasi karena kesengajaan ini yaitu digadaikannya mobil yang disewa oleh pihak penyewa kepada pihak ketiga, juga termasuk

${ }^{14}$ Ismu Gunadi dan Jonaedi Efendi, 2014, Cepat dan Mudah Memahami Hukum Pidana, Prenamedia Group, Jakarta,h.28. 
dalam strict liability, yaitu tanggung jawab mutlak akibat perbuatan melanggar hukum tanpa mempersoalkan kesalahan atau dengan kata lain tanggung jawab mutlak yang dimana kesalahan yang diperbuat tidak perlu dibuktikan lagi dan pertanggung jawaban tersebut didasarkan pada pelanggaran atas suatu kewajiban untuk menjaga sesuatu tetap aman. Pada kasus digadaikannya mobil tersebut, berarti pihak penyewa harus bertanggung jawab secara penuh tanpa perlu adanya pembuktian. Hal ini dikarenakan mobil yang disewa pada saat masa sewa, sudah beralih dan menjadi tanggung jawab pihak penyewa dan pihak penyewa wajib untuk menjaga dan berhati-hati untuk mempergunakan mobil yang disewa sesuai dengan kewajibannya.

2) Negligence tort liabity, merupakan tanggung jawab akibat perbuatan melanggar hukum yang dilakukan karena kelalaian. Bentuk wanprestasi karena kelalaian adalah dimana debitur tidak melakukan apa yang disanggupi akan dilakukan, melaksanakan apa yang diperjanjikan tetapi tidak sebagaimana mestinya dan melakukan apa yang diperjanjikan tetapi terlambat. Pada PT. Bali Radiance, sering terjadi wanprestasi karena kelalaian ini, yaitu berdasarkan data yang ada wanprestasi yang terjadi yaitu dimana pihak penyewa terlambat melakukan pengembalian mobil dan terjadinya kerusakan pada bagian-bagian mobil yang dilakukan oleh pihak penyewa. Hal tersebut sebenarnya sudah dijelaskan sebelumnya dalam surat perjanjian sewa menyewa mobil yang disepakati pihak penyewa dan PT. Bali Radiance. Pihak penyewa sering memberikan alasan atas wanprestasi yang dilakukan tetapi karena dalam surat perjanjian sudah mengatur wanprestasi tersebut, maka penyelesaian wanprestasi ini dilakukan sesuai dengan ketentuan yang ada di dalamnya. Berdasarkan wawancara dengan Saudara I Gede Widharma Putera, pihak yang pernah meminjam mobil di PT. Bali Radiance dan juga telah melakukan wanprestasi yaitu melakukan kelalaian yang mengakibatkan kerusakan pada mobil yang disewanya. Penyelesaian wanprestasi tersebut dilakukan dengan cara bernegosiasi. Pihak PT. Bali Radiance selaku pihak yang menyewakan, memberi pilihan kepada debitur bagaimana cara 
debitur dapat bertanggung jawab atas wanprestasi yang dilakukan. Pilihan tersebut adalah ${ }^{15}$ :

1) Pihak penyewa bertanggung jawab dengan memperbaiki sendiri atas kerusakan mobil yang disewa dan ditambah dengan biaya lamanya proses perbaikan mobil tersebut (sama dengan biaya sewa per hari).

2) Pihak penyewa hanya membayar biaya ganti rugi ditambah dengan biaya lamanya proses perbaikan mobil. Jadi, pihak PT. Bali Radiance yang memperbaiki mobil tersebut.

Pada kasus wanprestasi tersebut, pihak penyewa menyewa mobil Avanza (Manual) dengan biaya sewa Rp 250.000/hari dan memilih pilihan kedua, dimana mobil diperbaiki oleh PT. Bali Radiance dan pihak penyewa hanya membayar biaya ganti rugi ditambah dengan biaya tambahan karena lamanya proses perbaikan mobil selama 2 hari. Jadi debitur harus membayar biaya ganti rugi sebesar $\operatorname{Rp} 750.000+(2$ hari $x \operatorname{Rp} 250.000)=$ Rp 1.250.000. Jadi, biaya ganti rugi yang harus di bayar oleh pihak penyewa adalan $\mathrm{Rp} 1.250 .000$.

Penyelesaian wanprestasi lainnya, yaitu keterlambatan pengembalian mobil yang dilakukan pihak penyewa, dilakukan dengan membayar biaya ganti rugi yang juga sudah diatur dalam perjanjian sewa menyewa pada PT. Bali Radiance. Perhitungan biaya ganti rugi dihitung perjam dan biaya ganti rugi tersebut sebesar $\mathrm{Rp} 20.000$, misalnya pihak penyewa menyewa mobil Avanza dengan harga sewa Rp 250.000 dan penyewa terlambat melakukan pengembalian mobil selama 5 jam. Maka perhitungannya adalah $5 \times \mathrm{Rp} 20.000=\mathrm{Rp} 100.000$. Jadi biaya ganti rugi atas keterlambatan yang dilakukan pihak penyewa adalah $\mathrm{Rp} 100.000$. Biaya ganti rugi yang dilakukan oleh pihak penyewa atas wanprestasi yang dilakukan, terutama kerusakan mobil yang disewa, dapat dibayarkan baik secara tunai maupun kredit, tergantung dari negosiasi dan kesepakatan dari pihak penyewa dan pihak PT. Bali Radiance.

${ }^{15}$ Hasil wawancara dengan Saudara I Gede Widharma Putera, selaku pihak penyewa di PT. Bali Radiance, tanggal 18 September 2017 


\section{PENUTUP}

\section{Kesimpulan}

Pada perjanjian sewa menyewa mobil pada PT. Bali Radiance masih sering terjadi wanprestasi baik yang disengaja maupun yang tidak disengaja yang dilakukan oleh pihak penyewa yang merugikan PT. Bali Radiance. Oleh karena itu, pihak penyewa wajib untuk bertanggung jawab atas segala wanprestasi yang dilakukan. Adapun wanprestasi yang sering dilakukan oleh pihak penyewa pada PT. Bali Radiance adalah keterlambatan pengembalian mobil dan kerusakan pada mobil yang disewa karena kelalaian pihak penyewa. Kedua wanprestasi tersebut merupakan wanprestasi yang dilakukan karena kelalaian pihak penyewa dan pihak penyewa wajib untuk bertanggung jawab sesuai dengan penyelesaian wanprestasi yang telah ditetapkan pihak PT. Bali Radiance. Penyelesaian wanprestasi dapat dilakukan melalui dua jalur penyelesaian, yaitu penyelesaian melalui jalur litigasi (di pengadilan) dan jalur non litigasi (di luar pengadilan). Untuk wanprestasi yang terjadi pada PT. Bali Radiance tersebut, diselesaikan melalui jalur non litigasi yaitu negosiasi dan mediasi, dimana pihak penyewa melakukan ganti rugi atas kerugian yang dilakukannya. Adapun wanprestasi lainnya yang tergolong "berat", yaitu digadaikannya mobil yang disewa oleh pihak penyewa kepada pihak ketiga, akan diselesaikan melalui jalur litigasi atau pengadilan.

\section{Saran}

Adapun saran yang dapat penulis sampaikan yaitu :

1. Baik pihak penyewa maupun pihak yang menyewakan (rent car) harus dapat memahami dan melaksanakan seluruh isi perjanjian sewa menyewa mobil sebagaimana yang telah disepakati oleh kedua belah pihak, agar nantinya tidak terjadi sesuatu yang dapat merugikan salah satu pihak.

2. Apabila terjadi wanprestasi, wanprestasi tersebut dapat diselesaikan sebagaimana mestinya sesuai dengan hukum yang berlaku dan penyelesaian tersebut harus menguntungkan kedua belah pihak yang bersengketa (win-win solution) untuk menjaga nama baik rent car sebagai perusahaan serta menjaga hubungannya dengan pihak penyewa sebagai konsumen. 


\section{DAFTAR PUSTAKA}

\section{Buku:}

Gusadi, Ismu dan Efendi, Jonaedi, 2014, Cepat dan Mudah Memahami Hukum Pidana, Prenamedia Group, Jakarta.

Hernoko, Agus Yudha, 2014, Hukum Perjanjian, cet. Ke-4, Prenamedia Group, Jakarta.

Marbun, Rocky, 2011, Kasus Hukum, Visimedia, Jakarta.

Muhammad, Abdulkadir, 2010, Hukum Perusahaan Indonesia, Citra Aditya Bakti, Bandung.

Nurachmad, Much, 2010, Buku Pintar Memahami dan Membuat Surat Perjanjian, Visimedia, Jakarta.

Saija, Dr. Ronald, \& Letsoin, Roger F.X.V, 2016 Buku Ajar Hukum Perdata, Deepublish, Yogyakarta.

Saliman, Abdul R, 2015, Hukum Bisnis untuk Perusahaan, Prenamedia Group, Jakarta.

Sembiring, Jimmy Joses, 2011, Cara Menyelesaikan Sengketa di Luar Pengadilan, Visimedia, Jakarta.

Subekti, R, 2010, Hukum Perjanjian, cet. 23, PT. Intermasa, Jakarta.

Sudarsono, 2007, Kamus Hukum, PT. Rineka Cipta, Jakarta.

\section{Peraturan Perundang-Undangan:}

Undang-Undang No. 30 Tahun 1999 Tentang Arbitrase dan Alternatif Penyelesaian Sengketa.

Kitab Undang-Undang Hukum Perdata, 2014, diterjemahkan oleh Tim Wacana Intelektual, Cetakan Ke-1, Wacana Intelektual, Surabaya.

\section{DATA INFORMAN :}

Hasil wawancara dengan lbu Ni Ketut Candrawati S.S., selaku Staff Operational PT. Bali Radiance, tanggal 27 Agustus 2017.

\section{DATA RESPONDEN :}

Hasil wawancara dengan Saudara I Gede Widharma Putera, selaku pihak penyewa di PT. Bali Radiance, tanggal 18 September 2017 


\section{INTERNET :}

http://www.disparda.baliprov.go.id/id/Statistik3 diakses tanggal 30 Agustus 2017, diakses pada tanggal 16 Agustus 2017. 